\section{South Africa and science for all}

SIR-Certain critics of South Africa are now threatening to invade the arena of the natural sciences. The objects of this vociferous minority, in essence a congerie of ill-informed scientists and nonscientists, are to isolate our scientific community by impairing the free flow of scientists and scientific information to and from South Africa. The latest manifestation of this campaign is the attempt to preclude the attendance of South African scientists at the World Archaeological Congress.

I am the president of the South African Council for Natural Scientists, an autonomous body created by statute, which consists of eminent scientists nominated by their peers from all the branches of the natural sciences.

The council's terms of reference are to register adequately qualified natural scientists and to promote the interests of their profession; to protect public health, safety and interests generally against actions by inadequately qualified or nonqualified persons who venture into the natural scientist's field; and to administer a code of professional conduct for all registered natural scientists.

The council, which is totally non-racial, issued a policy statement early in 1985 in which it reaffirmed its attitude in support of the universality of science. It further expressed itself in favour of the free and unfettered pursuit of science and reasserted its constant aim to promote the interests of all natural scientists, irrespective of race, colour, creed or sex.

The proponents of South Africa's scientific isolation find justification (sic) for their actions in convoluted political arguments which are spurious in the very context of what science is all about: the pursuit of knowledge and the advancement of human capabilities. Surely scientific contribution or discovery cannot in the least be discounted or deemed irrelevant or less cogent merely because it emanates from a particular individual or country.

International boundaries and ideological barriers are totally irrelevant in the pursuit and exchange of knowledge. Scientific genius crops up without regard for country, language and race. The laws of nature are identical in all lands: they are there to be discovered and applied, accessible to the researchers of all nations. The natural scientist constantly endeavours to think in terms of realities that transcend parochial interests and personal aggrandizement: he is, in fact, a member of an international community. This we believe, and would commend to those attempting to disrupt the community of natural scientists.

It is common cause that scientists worldwide are, by and large, men and women who are intelligent, objective and fairminded. In the particular context of the subject matter of this appeal, these attributes have significantly come to the fore of late: large numbers of letters are being received by scientists in this country from their colleagues worldwide in which the pernicious activities of our would-be isola tionists are severely slated.

South African Council

for Natural Scientists,

Private Bag 11303, Brooklyn,

Pretoria 0011, South Africa

\section{Chinese forest}

SIR-In the article "South China's germplasm tank" (Nature 318, 220; 1985) there is a reference to what must be the Ding-hushan Forest Nature Reserve, an out-station of the South China Institute. It is not, as described, a 1,200-hectare arboretum and if it were, it would be by far the largest arboretum (tree collection) in the world. It is a largely untouched relic of natural subtropical forest which has remained so because it surrounded a temple and was regarded as sacred ground. Nor is it 1,200 hectares, but 300 hectares surrounded by 900 hectares of recent Pinus massoniana plantation buffer zone.

Your article says that Dinghushan may become one of the UNESCO Man and the Biosphere projects. It has been one for some time and this is proudly proclaimed at the entrance to the reserve.

Royal Forestry Society,

E.H.M. HARRIS

102 High Street,

Tring, Hertfordshire HP23 4AH, UK

\section{Bigfoot no joke}

SIR-As the leader of the "Bigfoot conservation group" that threatened to disrupt Mark Keller's armed Bigfoot hunt in 1984 (see Nature 313, 418; 1985) as well as a Loch Ness monster investigator (1982 and 1983), I should like to comment on what you say. First, our group wanted to stop Keller because we had no faith that he would not shoot some unarmed hiker in error. Then, we (Project Bigfoot) found almost no commercial interest in Bigfoot by chambers of commerce in the northwest. The local citizens simply wanted to stop hikers and others from running any risk in their woods from trigger-happy Bigfoot hunters. Bigfoot himself and his tribe seem to be able easily to avoid armed men, as Keller found after four months of no results.

But your main complaint seems to be that too much money and public commission time is being spent on what the writer feels is wasted effort. He wants that money/time spent on serious science, such as anti-pollution studies. In response, let me suggest that Bigfoot/Nessie/Chessie research may in time uncover some serious scientific information on the nature of energy-forms that we occasionally see but cannot catch or kill. The borderlands of science are often seen as a waste to study, but today's nonsense can often become tomorrow's serious scientific achievement.

ERIK BECKJORD

The Cryptozoology Museum,

18711 Pacific Coast Highway, Malibu, California 90265, USA

\section{Animal intelligence}

SIR-If man can be separated from animals only because he shows foresight, what can we make of the squirrel burying nuts in advance of the cold weather? Or the ants that show true agriculture with their fungus gardens? Andrejs Baidins' rule of thumb (Nature $\mathbf{3 1 9}, 172 ; 1986$ ) is as shaky as any other.

R. Powers

Department of Palaeontology,

British Museum (Natural History), Cromwell Road, London SW7 5BD, UK

\section{Acid rain from jets?}

SIR-Any motorist knows how corrosive exhaust fumes are on metal. No doubt aeroplane exhaust gases have much the same property, but since much of the emission from modern civil aircraft occurs at high altitudes, the vapour trails of droplets of ice containing any corrosive material must travel hundreds of miles to reach ground level. Where they eventually arrive will be governed by the variable weather conditions that they will encounter in falling, or being washed down in rain.

It would be of considerable interest and practical importance to take samples of air containing water vapour and disolved substances from the vapour trail area of the flight path of one of the large civil jets and to analyse the samples for "corrosive" content.

The present conventional hypothesis for the "acid rain effect" puts the blame on the water vapour contamination from the smoke stacks of industrial plant. But present coal consumption is only a little more than one-third of what it was in the $1900 \mathrm{~s}$, and even though oil firing is much increased since then, it seems unlikely that this source could be the main factor responsible for the quite recent rapid worsening of the mortality of trees due to acid rain. If this was the main cause, why were not its effects much more severe in the early years of this century? Atmospheric pollution on a large scale due to aircraft exhaust fumes is a much more recent phenomenon; this may be the cause.

FRANK PYGOTT

Navigation Cottage, Willoughby,

Rugby, Warwickshire CV23 8AG, UK 